\title{
Development of green environmental: policy in education
}

\author{
Saule Sarbassova ${ }^{1, *}$, Sairan Abdugalina ${ }^{1}$, Roza Burganova $^{1}$, Kazna Shaikheslyamova ${ }^{1}$, \\ Banugul Abdrasheva ${ }^{2}$ and Gaziza Jamaliyeva² \\ ${ }^{1}$ Kazakh University of Economics, Finance and International Trade, 7, Zhubanov str., 010005, Nur- \\ Sultan, Republic of Kazakhstan \\ ${ }^{2}$ Karagandy State University named after E. A. Buketov, 28, Universitetskaya str., 100009, \\ Karaganda, Republic of Kazakhstan,
}

\begin{abstract}
The need to overcome the environmental problems of our time has set a task for pedagogical theory and practice: on the basis of the biosphere approach, to prepare an environmentally literate person who understands the importance of life as the highest value, who is able to determine his place in the world, participate in environmental protection, rationally use natural resources, make conscious decisions in the spheres of life where the interests of man as a living being, society and the environment overlap. In the system of training an environmentally literate person, an important role belongs to educational organizations of all levels, which can be considered as the initial link in enriching a person with knowledge about the natural and social environment, familiarizing him with a holistic picture of the world and forming a scientifically grounded, humane attitude towards society. Environmental education is designed to provide the young generation with scientific knowledge about the relationship between nature and society, to help understand the multifaceted significance of nature for society in general and for each person in particular, to form an understanding that nature is the primary basis of human existence, and man is a part of nature, to educate a conscious attitude towards it, a sense of responsibility for the environment as a universal value, develop creative activities to protect and transform the environment, cultivate love for nature. Environmental education and upbringing is a systematic pedagogical activity that is aimed at developing the environmental culture of a person. Environmental education of a person is a continuous process of learning and development throughout his life, which is expressed in the formation of an ecological culture, which manifests itself in an emotional and positive attitude towards nature, in compliance with certain moral norms, in a system of value orientations.
\end{abstract}

\section{Introduction}

The relevance of the issue of environmental education is due to the significant expansion of the sphere of humanistic regulation, its extension to the natural and artificial

\footnotetext{
* Corresponding author: kostrova1034@gmail.com
} 
environment, human life. Here we are talking about subordinating the technological process to the settings of a humanistically oriented rational policy and making it controlled by the requirements of moral responsibility for balanced and sustainable socio-economic development. The new vector of sustainable socio-economic development has caused a whole range of innovative factors that have caused a fundamental civilizational turn in the history of mankind, and have created a worldwide process called "Globalization". Globalization is the process of forming a new world society, which is based on the integration and transnationalization of environmental, economic, political and other types of activity, which should function on the basis of generally recognized values in the modern world. Globalization as a complex process has important prerequisites, such as "... information revolution; internationalization of capital and increased competition in world markets; depletion of natural resources and increased man-made pressure on nature. Environmental education is a relatively new area of pedagogical theory and practice. It should ensure the implementation of fundamental general didactic provisions, such as consistency and systematicity, continuity and continuity, humanization and scientific character. The need to implement these principles enhances the integral function of subjects in an educational organization. Within the framework of modern education, environmental knowledge is an important aspect in the formation of environmental awareness, and, therefore, all education should be environmental. At the same time, environmental knowledge is the essential basis of environmental education, which involves the assimilation of systematized environmental knowledge and contributes to the formation of environmental consciousness, that is, awareness of the unity of man and nature. Ecological knowledge should be fundamental in technical, economic, humanitarian knowledge, reveal an understanding of the "relationship between man and nature. In order to "clarify the substantive aspect of environmental knowledge," we consider it in the historical and philosophical terms. Modern society pays more and more attention to the philosophical understanding of new views on environmental problems. A large number of scientific studies by authors from near and far abroad are devoted to the study of environmental knowledge, among which certain scientific concepts can be distinguished. There is no single agreed thought on resolving the environmental issue. This is explained, on the one hand, by the complexity of the ecological problem, and, on the other hand, by the insufficient development of the theoretical foundations of ecological knowledge. Over the past decades, scientific ideas about environmental knowledge have changed many times. So, one of the directions covers work devoted to the study of theoretical and methodological aspects, the state and prospects of development and human relations with the natural environment.

\section{Literature review}

The problem of the relationship between man and nature has emerged as a subject of study by many thinkers in various fields of scientific knowledge of the past and present. Back in the 17th century, Jan Amos Comenius drew attention to the conformity of all things to nature, that is, to the fact that all processes in human society proceed like the processes of nature. He developed this idea in his work The Great Didactics. The epigraph to this book was the motto "Let everything flow freely, without the use of violence [1]". Comenius argued that nature develops according to certain laws, and man is a part of nature, therefore, in his development, man obeys the same general laws of nature [2-4] The Russian enlighteners V.G. Belinsky, A.I. Herzen, N.A. Dobrolyubov, D.I. Pisarev, N. Chernyshevsky. They emphasized the role of natural knowledge in the formation of the moral qualities of an individual that regulate human behavior in nature. The ideas of teachers of the past about the educational value of nature were reflected in the activities of 
domestic methodologists in the field of education Ya. Gerda, A.I. Beketov, K.A. Timiryazeva, D.N. Kaigorodov and many others. One of the strategic directions in university education was proclaimed a large-scale project of environmental education, i.e. greening of university disciplines. However, at present there is no unified interpretation of this term yet. So, according to N.F. Reimers, greening is the penetration of environmental ideas into all spheres of public life. Greening is further written by N.F. Reimers - in the end is designed to preserve the possibility of existence and development of a long chain of generations of people within the framework of the law of unity of the organismenvironment and the rules of conformity of environmental conditions to the genetic doom of the organism. In the long term, he described greening as a path of social development, determined by global environmental constraints [5-7]. I.P. Gerasimov defined the concept of "greening" as "a set of methods and means of optimizing nature management $[8,9]$ ". According to I.P. Gerasimov's main goals of greening: 1. Optimization of the living conditions of mankind by preserving and improving the properties of the natural environment; 2. Transition of production to waste-free technologies and closed cycles of resource consumption; 3. Rational use of natural resources, which ensures their protection, restoration and expanded reproduction; 4. Protection and preservation of the gene pool of flora and fauna. AND I. Blekhtsin and V.Ya. Mineev define ecologization as a principle of ecology, which is to recognize the close relationship of various forms and manifestations of modern life with the environment [10]. V.P. Maksakovsky believes that greening involves considering a person in an inextricable connection with the environment. "Greening, as the direction he notes, is also characteristic of the entire interdisciplinary complex of sciences, which studies the interaction of society, production and the environment or ecodevelopment [11]". Summing up the statements of researchers about the interpretation of the term "greening", it should be noted that he received many interpretations: the greening of science, technology, education. According to N.F. Reimers, general greening means a versatile, systemic, than before, approach to the objective world and more awareness of the role of nature in human life [12]. According to N.M. Mamedova: "Close attention should be paid to such issues as the greening of the education system, the formation of environmental awareness, increasing the social and environmental responsibility of a person [13]". In his views on environmental education, N.M. Mammadov believes that greening involves the inclusion of environmental aspects in all educational subjects, greening the learning process, greening the environment of educational institutions, greening the teacher-student relationship [14]. At the same time, a number of researchers believe that the greening of education is not a mechanical addition to general education, but is an organic component of the education system as a whole. Talking about the implementation of the ecological approach in higher education. V.V. Nikolina notes that along with the greening of all university disciplines, it is necessary to simultaneously include in the curricula of integrated environmental courses: "Nature management", "Ecology", "Global ecology" [15]. According to V.S. Preobrazhensky, the greening program should be focused, first of all, on the ecological education of the citizen, the human impact on the environment. Summarizing what has been said, it can be argued that most scientists adhere to the idea that greening is a process of forming the student's ecological consciousness. Moreover, it is not a mechanical addition to general education, but acts as an organic component of the education system as a whole.

\section{Results}

In recent years, environmental education and environmental education have become the subject of careful research by outstanding representatives of pedagogical science. Perhaps the most significant contribution to the formation and formation of the ecological direction 
in pedagogy was made by A.N. Zahlebny [16]. He owns the idea of the existence of such fundamental principles of environmental education and upbringing (table 1).

Table 1. Fundamental principles of environmental education. Source: compiled by the authors.

\begin{tabular}{|l|l|}
\hline № & \multicolumn{1}{|c|}{ Principles } \\
\hline 1 & The relationship of global, national and local history approaches \\
\hline 2 & The principle of cooperation \\
\hline 3 & The principle of predictability \\
\hline 4 & The principle of interdisciplinarity \\
\hline 5 & The principle of the unity of theory and practice \\
\hline 6 & The principle of continuity \\
\hline 7 & $\begin{array}{l}\text { The unity of the intellectual and emotional perception of the surrounding reality } \\
\text { in the practical activity of preserving it, caring for it and improving its qualitative } \\
\text { and quantitative composition }\end{array}$ \\
\hline
\end{tabular}

S.M. Glazachev and S.E. Petrov $[17,18]$. They are characterized by the identification of the terms "environmental education" and "environmental education", which directs the process of environmental education mainly to protect the natural environment of human habitation. In addition, they refer to the principles of education:

- the principle of complementarity of environmental education in all other areas of educational work with people;

- the principle of using the educational (educational) function of nature, which is changing and protected;

- the principle of combining consideration of the problems of nature protection on a global scale and in a specific area.

In general, it should be noted that the principles of organizing environmental education were collectively determined by representatives of the countries participating in the Council for Mutual Assistance [19].

Here they are:

- in the process of environmental education, one should take into account the interconnection of global, national and local history approaches to the disclosure of environmental problems of our time;

- environmental education and upbringing are considered as an integral part of a holistic upbringing process;

- ensuring the unity of intellectual and emotional perception of the reality around us and practical work to improve it and protect it from various influences on it;

- preservation of the principles of systematicity, continuity, and interdisciplinarity in the content and organization of environmental education and upbringing. These principles formed the basis of the entire organization of environmental education and environmental education in the recent past. It can be argued that they belong to the significant methodological achievements of pedagogical science and practice, and had a significant impact on the process of organizing educational work in educational organizations of all levels. There is, perhaps, no need to justify their practical value in our days. A characteristic feature of the concepts of environmental education is the analysis of the influence of nature, its phenomena and processes on the formation of the personality of a university graduate his social, physical, intellectual, artistic and aesthetic formation. In the development of ecoculture, one should focus on the programmatic goal of environmental education and upbringing, first of all on its humanistic component: attitude to nature is attitude to oneself, because man and nature are deeply closely interconnected. This is what gives a full sense of the meaning and uniqueness of life [19-23]. Environmental education of a person is a continuous process of learning and development throughout his life, which is expressed in the formation of an environmental culture, which manifests itself in an emotional and 
positive attitude towards nature, in compliance with certain moral norms, in a system of value orientations.

\section{Discussion}

The transition of society to sustainable development is an ecological reorientation, first of all, of education. There should be a different philosophy, politics, morality, a system of values that would not be dependent on either socio-economic or political issues, and which, in turn, would consider the preservation of nature and man to be the absolute value of life. Education for sustainable development provides for the renewal of the educational process, the introduction of educational methodologies that can reorient the training system, and will educate future specialists capable of making environmentally important decisions. The history of mankind is inextricably linked with the history of nature. At the present stage, the issues of its traditional interaction with humans have grown into a global environmental problem. People should learn to take good care of nature in the near future. And for this it is necessary to foster ecological culture and responsibility. Not every person has the opportunity to become familiar with the understanding of environmental problems at the level of big science; the idea of these problems sometimes develops in a very random way: under the influence of ordinary impressions or from media reports. Scattered information does not allow a person to develop a harmonious system of environmental knowledge, which he needs in order to reasonably treat nature, not to harm it. The task of society here is to ensure the systemic nature of the ecological education of the population.

The state tuition for the top 5 institutions with the most degrees awarded in Environmental Education (figure 1).

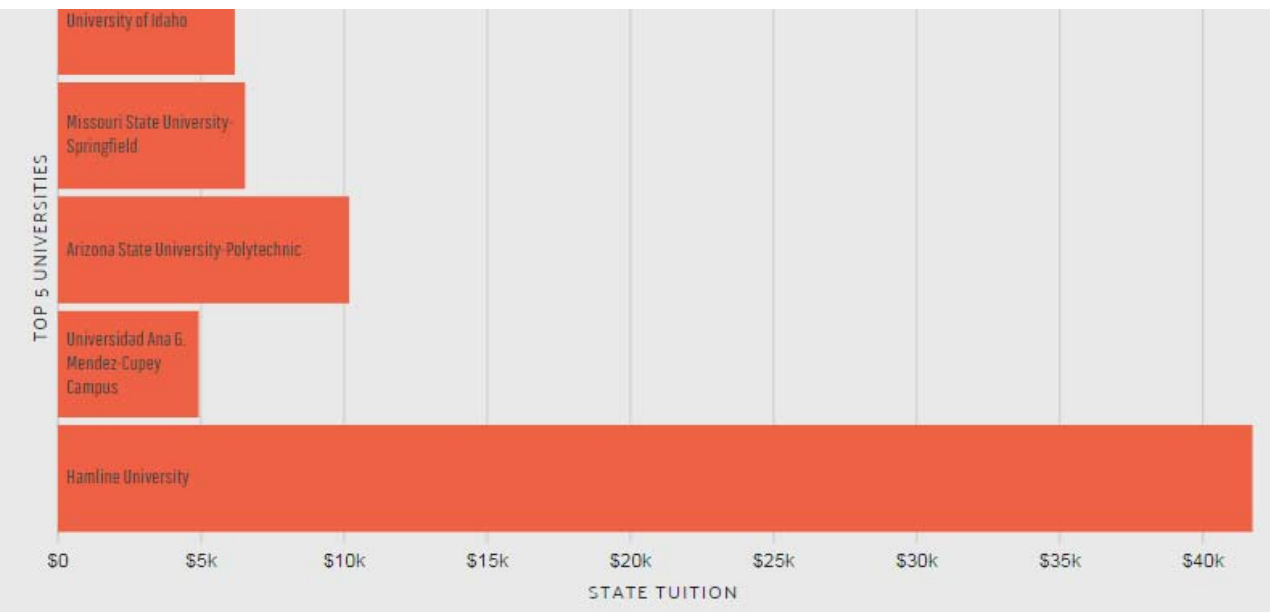

Fig. 1. The state tuition for the top 5 institutions with the most degrees awarded in Environmental Education. Source: https://datausa.io/profile/cip/environmental-education.

The possibility of a radical change in the current situation associated with the scientific development of the problems of environmental education on the basis of the prospects for the transition of mankind, discovered by modern philosophers and culturologists, to the noospheric civilization through the establishment of eco-cultural values in society. The need to strengthen the impact on the spiritual sphere of the individual, the formation of the moral component of ecological culture, is becoming more and more clear, is the prerogative of the process of ecological education. At each age stage of personality development, ecological culture has its own specific characteristics. An increase in the level of ecological 
education of the young generation is directly dependent on the completeness of scientific ideas about the originality of the process of environmental education at each age segment and its practical implementation, taking into account the identified features. Thus, as a result of all of the above, we can conclude that the need for greening the sphere of education and upbringing appeared a very long time ago in the works of outstanding teachers. Well-known figures noted the great social and educational value of ecologists, because this science not only raised the level of aesthetic culture of students at all levels of education, but also contributed to the development of logical thinking and imagination. Unfortunately, the concepts of these teachers were not always appreciated at their true worth, and environmental education and upbringing was formally introduced into universities and was only partially applied. As a result, we have whole generations of people with a low level of ecological self-awareness.

\section{Conclusion}

An important result of the work is the study of the need for the transition of a sustainable development strategy. The concept of sustainable development provides for the development of society aimed at meeting the needs of present and future generations. This goal cannot be achieved without the interaction of three components: economic, social and environmental. This provision is complemented by the fact that the sustainable development of society is impossible without the interconnection of "the connection of socio-political, economic, economic, scientific and technical, moral and cultural components. At the same time, for today's solution of "Commitment to environmental problems, a complex combination of educational, environmental, economic, social, political and other factors in the development of society and the state is necessary. It has been determined that environmental education, its scientific support is a priority in the concept of sustainable development, and then its next task in the formation of a person's life-value orientations will be the desire for an organic combination of rational and emotional content in the consciousness of a person, in his relation to nature. Based on the foregoing, we conclude that environmental knowledge should be fundamental in technical, economic, humanitarian sciences and reveal an understanding of the relationship between man and nature. Based on the analysis of theoretical and practical material, it was revealed that environmental education should be a basic component of both technical and humanitarian disciplines. We believe that the time is ripe for the harmonization of relations between man and nature, which is possible only on condition of assimilation of ecological knowledge and understanding by man (society) of his responsibility for the state of nature and life in general.

\section{References}

1. O. Artemenko, S. Anzorova, P. Gasanova et al., Bulletin the National academy of sciences of the Republic of Kazakhstan 5(387), 226 - 232 (2020) https://doi.org/10.32014/2020.2518-1467.162

2. Sh. Niyazbekova, B. Jazykbayeva, A. Mottaeva et al., E3S Web Conf. 244, 10058 (2021) DOI: https://doi.org/10.1051/e3sconf/202124410058

3. E.Yu. Nikolskaya, S.P. Anzorova, S.V. Potapov et al., Journal of Environmental Management and Tourism 9.8(32), 1664-1669 (2018)

4. Sh. Niyazbekova, L. Moldashbayeva, S. Kerimkhulle et al., E3S Web Conf. 244, 10060 (2021) DOI: https://doi.org/10.1051/e3sconf/202124410060 
5. Z. Yessymkhanova, Sh. Niyazbekova, Zh. Dauletkhanova et al., E3S Web Conf. 244, 01016 (2021) DOI: https://doi.org/10.1051/e3sconf/202124401016

6. Sh. Niyazbekova, S. Yerzhanova, Yu. Tyurina et al., E3S Web Conf. 244, 10059 (2021) DOI: https://doi.org/10.1051/e3sconf/202124410059

7. Sh. Niyazbekova, M. Troyanskaya, S. Toygambayev et al., E3S Web Conf. 244, 10054 (2021) DOI: https://doi.org/10.1051/e3sconf/202124410054

8. A. Mottaeva, N. Kalinina, A. Kuzmina et al., E3S Web of Conferences 91, 08072 (2019) doi.org/10.1051/e3sconf /20199108072

9. A. Nurpeisova, G. Mauina, S. Niyazbekova, et al., Entrepreneurship and Sustainability Issues 8(2), 682-697 (2020) https://doi.org/10.9770/jesi.2020.8.2(41)

10. T.A. Kozenkova, Z.E. Suleymanov, T.V. Abalakina et al., Studies in Systems, Decision and Control 316, 1105-1115 (2021)

11. I. Markina, A. Sharkova, M. Barna, International Journal of Entrepreneurship 22(3) (2018)

12. N.Y. Ryazanova, A.V. Sharkova, N.E. Lobzhanidze et al., International Journal of Recent Technology and Engineering 8(1), 2691-2695 (2019)

13. E.L. Moreva, L.V. Obolenskaya, A.V. Sharkova, Studies in Systems, Decision and Control 314, 511-519 (2021)

14. K. Kunanbaeva, S. Rahimova, A. Pigurin, E3S Web of Conferences 164, 01031 (2020)

15. S. Rakhimova, L. Goncharenko, S. Sybachin et al., E3S Web of Conferences 210, 10006 (2020)

16. M.S. Iskakova, M.K. Abenova, L.N. Dzhanmuldaeva et al., Journal of Environmental Management and Tourism 12(2), 466-472 (2021)

17. A.N. Dogalov, K.Z. Sadvokasova, B.O. Turebekova et al., Life Science Journal 11(11), 550-555 (2014)

18. A. Madysheva, T. Imangulova, M. Khudzhatov et al., Academy of Strategic Management Journal 20(2), 1-9 (2021)

19. R. Mugauina, I. Rey, R. Sabirova, A.E. Zhansagimova, Journal of Environmental Management and Tourism 11(8), 2020-2027 (2020) ISSN 2068-7729

20. A.E. Zhansagimova, T.A. Azatbek, S.U. Niyazbekova, Actual Problems of Economics 149(11), 332-337 (2013)

21. K. Kunanbayeva, A. Gorovoy, A. Butyrin, MATEC Web of Conferences 193, 05048 (2018) DOI: 10.1051 / matecconf / 201819305048

22. S. Rakhimova, K. Kunanbayeva, et al., E3S Web of Conferences 110, 02154 (2019) DOI: 10.1051 / e3sconf / 201911002154

23. K. Kunanbaeva, S. Rahimova, A. Titkov et al., E3S Web of Conferences 164, 03049 (2020) DOI: 10.1051 / e3sconf / 202016403049

24. M. Troyanskaya, G. Dugalova, E. Adietova et al., Sustainable hotel development. Academy of Strategic Management Journal 20(2), 1-16 (2021)

25. https://datausa.io/profile/cip/environmental-education 